\title{
Questes
}

vestes Revue pluridisciplinaire d'études médiévales

\section{Paysages de la mémoire}

\section{Paysages de la mémoire : avant-propos}

\section{Michel Zink}

\section{(2) OpenEdition}

\section{Journals}

\section{Édition électronique}

URL : http://journals.openedition.org/questes/2566

DOI : 10.4000/questes.2566

ISSN : 2109-9472

\section{Éditeur}

Les Amis de Questes

\section{Édition imprimée}

Date de publication : 15 décembre 2002

Pagination : 3

ISSN : 2102-7188

\section{Référence électronique}

Michel Zink, «Paysages de la mémoire : avant-propos », Questes [En ligne], 2 | 2002, mis en ligne le 01 janvier 2014, consulté le 25 septembre 2020. URL : http://journals.openedition.org/questes/2566 ; DOI : https://doi.org/10.4000/questes.2566 
Prendre la peine d'entrer en contact les uns avec les autres, d'organiser un séminaire, de publier un bulletin : voilà, de la part de jeunes doctorants qui pourraient avoir chacun pour seul souci de boucler sa thèse au plus vite dans son coin, le signe le plus sûr d'un enthousiasme généreux et vrai pour l'objet de nos études, le Moyen Age. Une université, celle de Paris-Sorbonne, qui est la plus importante de France pour les disciplines de la mémoire; des maîtres illustres dirigeant des thèses nombreuses dans tous les domaines des études médiévales: voilà qui donne à l'entreprise les meilleures chances de succès. Enfin, le premier thème retenu ne pouvait être mieux choisi. Il n'est pas d'enjeu plus important, s'agissant d'une époque rétrospectivement désignée comme un âge intermédiaire, que son inscription dans la mémoire et ses représentations du temps. Il n'est pas de sujet où se rencontrent aussi naturellement l'histoire elle-même et celle des idées, l'étude de la langue et celle des textes, celle de l'imaginaire et des sensibilités.

Puisque les jeunes collègues qui ont pris cette heureuse initiative m'ont fait l'honneur de me demander ma bénédiction, qu'ils me permettent, par une indulgence due au grand âge, de la faire suivre d'une brève homélie, depuis l'autre rive de la rue Saint-Jacques comme depuis l'autre monde. Leurs rencontres seront fécondes si elles sont l'occasion, non seulement d'échanger leurs idées et de parler de leurs travaux, mais aussi d'accroître leurs compétences. Rappelons-le une fois de plus : on ne peut se prétendre médiéviste sans connaissance suffisante du latin et sans reconnaissance $\mathrm{du}$ rôle fondamental «des disciplines chartistes », comme on les appelle parfois. L'érudition ne doit pas, certes, stériliser la pensée, mais toute pensée est faible sans l'appui de l'érudition. 